\title{
Different but the same: bumblebee species collect pollen of different plant sources but similar amino acid profiles
}

\author{
Linda Kriesell ${ }^{1}$, Andrea HiLPERT ${ }^{2}$, Sara D. LeONHARDT ${ }^{1}$ \\ ${ }^{1}$ Department of Animal Ecology and Tropical Biology, University of Würzburg, 97074, Würzburg, Germany \\ ${ }^{2}$ Institute of Biology, Technical University of Darmstadt, 64287, Darmstadt, Germany
}

Received 18 December 2015 - Revised 11 May 2016 - Accepted 25 May 2016

\begin{abstract}
Access to abundant and diverse floral plant sources is essential for generalist bees as they obtain all energy and nutrients required from pollen and nectar. Despite their importance, we still know little about the precise nutritional requirements of most bee species. Here, we investigated differences in floral and amino acid profiles of pollen collected by five bumblebee species in southern Germany, which had access to the same spectrum of plant species and thus sources of nutrition. We found that different bumblebee species visited different floral spectra for pollen collection but nevertheless had highly similar pollen amino acid profiles. This finding suggests that common bumblebee species only slightly differ in their nutritional target for amino acids in pollen. In fact, floral and chemical composition of pollen loads appear to be largely determined by the plant community present at a site as bumblebees attempt to maximize site-specific nutrient collection efficiency.
\end{abstract}

\section{bee foraging / insect nutrition / plant-insect interactions / pollen chemistry / resource use}

\section{INTRODUCTION}

Bees are the dominant pollinators of crop and wild plant species in most ecosystems (Neff and Simpson 1993; Waser and Ollerton 2006), with the (primitively) eusocial species, i.e., honeybees and bumblebees, playing a particularly important role in Europe and North America (Klein et al. 2007). Here, many wild bee species have disappeared or reduced their distribution ranges over recent decades, while the number of managed honeybee hives has simultaneously declined (Biesmeijer et al. 2006; Potts et al. 2010a, b; Goulson et al. 2015).

Why pollinators decline remains subject to debate, but human activities, particularly agricultural intensification, the use of pesticides and herbicides and habitat conversion, have frequently

Corresponding author: S. D. Leonhardt, sara.leonhardt@uni-wuerzburg.de

Manuscript editor: James Nieh been named as culprits (Winfree et al. 2009; Goulson et al. 2015). Notably, all these anthropogenic activities directly or indirectly affect the availability and diversity of flowering plants and hence the bees' food sources, rendering the abundance, distribution/availability, quality, and diversity of resources the potentially major driver in the foraging and population dynamics of bees (Roulston and Goodell 2011; Vaudo et al. 2015). Accordingly, the decline of bee species strongly correlates with the decline of their preferred plant species (Biesmeijer et al. 2006; Scheper et al. 2015). The abundance of several bumblebee species is further positively correlated with high flowering plant diversity as well as with the presence of particular plant families (Williams 1986; Mänd et al. 2002; Hines and Hendrix 2005; Goulson et al. 2006; Hülsmann et al. 2015). The significant role of flowering plant species abundance, diversity, and composition may not be surprising given that bees rely entirely on floral resources to feed themselves and their colonies (Michener 2007). They consequently obtain all 
required nutrients from pollen and nectar (Keller et al. 2005). While nectar primarily contains carbohydrates which meet basic energetic needs, most other macronutrients (i.e., lipids and protein) as well as essential vitamins and minerals are obtained from pollen (Roulston and Cane 2000). This comprehensive nutritional role of pollen likely explains why pollen foragers are generally more selective in their choice of food plants than nectar foragers (Wcislo and Cane 1996; Goulson and Darvill 2004). It is however still largely unknown whether and how pollen nutritional composition (hitherto referred to as nutritional quality) drives pollen foraging patterns in generalist bees, or whether different species differ in their nutritional requirements and thus pollen foraging patterns (Vaudo et al. 2015). This knowledge is however essential for understanding the relationship between alterations in the composition of available resources and bee health.

Hitherto, several studies have analyzed the nutritional content of pollen of plant species foraged by individual bees (Rayner and Langridge 1985; Roulston and Cane 2000; Roulston et al. 2000; Manning 2001; Cook et al. 2003; Sommerville and Nicol 2006; Szczêsna 2006; Hanley et al. 2008; Tasei and Aupinel 2008; Weiner et al. 2010; Nicolson 2011; Di Pasquale et al. 2013; Avni et al. 2014; Vanderplanck et al. 2014a, b; Somme et al. 2015). Most of these studies focused on crude protein content or amino acid composition of pollen, while even fewer have analyzed other nutrients, such as lipids, sterols, vitamins, or minerals (recently reviewed by Vaudo et al. 2015).

These studies suggest that social bees do not simply mix pollen but select pollen of specific nutritional properties, e.g., high protein (or overall amino acid) content (Regali and Rasmont 1995; Goulson et al. 2005; Hanley et al. 2008; Kitaoka and Nieh 2009; Scheper et al. 2015), high lipid content (Di Pasquale et al. 2013), high phytosterol content (Somme et al. 2015), or the protein to lipid ratio (as suggested by Vaudo et al. 2015).

To better understand how the floral composition of pollen collected by different bumblebee species affects the nutritional quality of pollen in terms of amino acid concentration and composition and whether different species differ in their "amino acid target", we collected and analyzed pollen from five common bumblebee species which all foraged for pollen at the same suburban/periphery site in Germany.

Because different insect species are known to have different nutritional targets (i.e., require different ratios of particular nutrients) (Behmer 2009), we hypothesized that both the plant species visited for pollen collection and the proportions of different amino acids varied among species.

\section{METHODS}

\subsection{Study site, species, and pollen sampling}

The study was conducted in Würzburg, southern Germany, between April and July 2014. All bumblebees were collected at the Hubland campus of the University of Würzburg which comprises a $\sim 1.3 \mathrm{~km}^{2}$ area with buildings, plantings, hedges, and fruit trees, surrounded by gardens, rapeseed, and wheat fields, small forest patches, and additional grasslands and hedgerows. The study area consequently represented a relatively heterogeneous landscape with ample forage opportunities.

Observations and pollen sampling took place between 8 am and 5 pm at overall 120 mostly non-rainy days. Walking along the trails on and around campus, we stopped at all patches with flowering plants and observed each patch between 10 and $30 \mathrm{~min}$. If possible, all bumblebees visiting flowers at a patch were caught using an insect net and plastic tube (on average $18 \pm 22$ bumblebees per patch). Where too many bees were foraging simultaneously, we caught those foragers that were closest to the observer. Each patch was only visited once per day. All foragers caught at a patch were kept in plastic tubes for identification and to prevent double-counting. Their hind legs were inspected for pollen. Bees with pollen loads were considered pollen foragers, and bees without any visible pollen on their hind legs were considered nectar foragers. Because we could not collect nectar from nectar foragers without killing bees, nectar foragers may also have comprised scouts or pollen foragers which had just started foraging. All bees were subsequently immobilized in a freezer $\left(-20^{\circ} \mathrm{C}\right)$ for approximately $2-10 \mathrm{~min}$. Pollen loads were removed with clean forceps, and all bees were finally identified using the key of Amiet (1996) 
before releasing them close to their original foraging patch. To assess whether loads of pollen foragers actually and exclusively contained pollen from the plant species they were captured from, we additionally identified all plant species visited by bees (Schmeil and Fitschen 2011).

Pollen loads were placed into clean Eppendorf tubes with the two loads from both hind legs of a forager kept in two separate Eppendorf tubes. One load was used for palynological analyses, while the other one was analyzed chemically to obtain amino acid profiles. For individuals with very small pollen loads, both loads were pooled and only analyzed chemically (11 foragers). Three pollen foragers carried minute pollen loads which were not sufficient for any analysis.

\subsection{Palynological analysis}

To identify plant sources of pollen loads obtained from bumblebees and to analyze the degree of floral specialization of different species, we prepared permanent glycerine-gelatin microscope slides for overall 39 pollen loads following the protocol as described in Leonhardt and Blüthgen (2012).

Pollen grains were characterized by morphospecies under a microscope at a magnification of $\times 400$. We characterized overall 35 pollen morphospecies. Sixteen morphospecies could be identified to the plant family (3), genus (4), and species (9) level by following the pollen identification key of Beug (2004) and by comparing pollen grains to a reference collection containing 639 flowering plant species growing in the study area. The other morphospecies could not be reliably identified to species, genus, or family level, but they could be assigned to different plant species, thus allowing for inferences on species-specific differences in plant sources visited for pollen foraging.

To quantify the number of different pollen morphospecies for each pollen load, all grains covering the area visible under $\times 400$ magnification were counted and categorized according to one of the 35 characterized morphospecies (hitherto referred to as pollen type). The procedure was repeated for five randomly chosen non-overlapping areas per slide/pollen load, and pollen grain numbers were summed up (between 21 and 277 grains per bee) for each pollen type to obtain a proximate for relative proportions of each pollen type within a slide/pollen load.

\subsection{Amino acid analysis}

We analyzed free and protein-bound amino acids of overall 47 pollen loads by ion exchange chromatography (IEC: Biochrom 20 plus amino acid analyzer) also following Leonhardt and Blüthgen (2012). Briefly, each pollen load was mixed with $6 \mathrm{~N} \mathrm{HCl}$, boiled $4 \mathrm{~h}$ at $100{ }^{\circ} \mathrm{C}$, cooled down to room temperature, and centrifuged (10 min). The supernatant was transferred into a fresh tube, and water was evaporated at $100{ }^{\circ} \mathrm{C}$. The sample was re-dissolved thrice in fresh water and centrifuged again. Then $100 \mu \mathrm{L}$ was mixed with $12.5 \%$ sulphosalicylic acid and extracted in the refrigerator (30 min). After short mixing and centrifuging (10 $\mathrm{min}), 100 \mu \mathrm{L}$ of the supernatant was mixed with $100 \mu \mathrm{L}$ sample rarefaction buffer in a fresh microcentrifuge tube, filtered, and centrifuged, and the sample was finally analyzed by IEC.

\subsection{Statistical analyses}

The effects of bumblebee species on the variation in pollen type collection (i.e., floral visitation/partitioning) as well as overall amino acid profiles were analyzed by permutation tests (PerMANOVA, using 10,000 permutations) based on Bray-Curtis distances between pollen types/amino acids (Oksanen et al. 2015). For pollen types, analyses were based on the proportion of each pollen type (obtained by dividing the number of pollen grains of each pollen type by the overall number of pollen grains found in a particular pollen load). For amino acids, separate permutation tests were performed for concentrations [in $\mathrm{mg} / \mathrm{g}$ dry weight] and relative proportions of overall amino acids. Proportions of individual amino acids were obtained by dividing the concentration of each individual amino acid by the total concentration of all amino acids analyzed per pollen load.

Species-specific differences in total amino acid content as well as concentrations of single amino acids were analyzed using analyses of variances (ANOVA) followed by Tukey post hoc tests. If necessary, concentrations were log- or squareroot-transformed to achieve normality and homogeneity of variances. Amino acid proportions were arcsine-squareroot-transformed as suggested by Sokal and Rohlf (1981).

Because data on pollen types was largely zero-inflated, we did not analyze species-specific differences for each pollen type. Instead, we performed separate 
permutation tests for all two species comparisons and corrected for multiple testing using sequential Bonferroni.

To examine whether species-specific differences in flower visitation patterns translated into differences in the overall amino acid profile of pollen collected, we calculated the quantitative networklevel specialization index $\mathrm{H}_{2}$ ' (Blüthgen et al. 2006) using the bipartite package in R. $H_{2}$ ' was used to assess the degree of (1) floral partitioning based on observations (visitation network), (2) floral partitioning based on palynological analyses (pollen type network), and (3) chemical partitioning (with regard to amino acids, nutritional network) across bumblebee species. For analyzing the pollen type network, we considered the presence of each pollen type/pollen morphospecies in the load of a forager as one visit to this plant species, as we found this approach most comparable to the actual visitation network. Thus, links in the network were weighted by the number of pollen loads sampled for a given bumblebee species which contained a specific pollen type/morphospecies. Chemical partitioning was calculated for both the species' mean concentrations and mean proportions of each amino acid. The specialization index ranges from 0 (i.e., pollen samples from all species have a similar floral/amino acid composition) to 1 (each species collects pollen from a different plant species spectrum/with a unique amino acid profile).

All species with less than three foragers were excluded from statistical analyses (i.e., Bombus lucorum and Bombus pascuorum from analyses on speciesspecific amino acid profiles and Bombus humilis, B. lucorum, and B. pascuorum from analyses on species-specific differences in pollen types collected). All statistical analyses were conducted with $\mathrm{R}$ version 3.0.2 (R Development Core Team 2015).

\section{RESULTS}

Between April and July, overall 160 bumblebee foragers (110 nectar and 50 pollen foragers) of seven species were caught from overall 19 different plant species (eight families) (Table I). Most bees were caught from Lamiaceae $(27,17 \%)$ and Fabaceae $(18,10 \%)$ (Table I).

The only pollen foragers with pure pollen loads were those collected from Lonicera spp. (2 foragers) and Plantago lanceolata (1), while all other foragers had at least two and up to ten different types of pollen grains in their loads (on average $4 \pm 3$ pollen types, Table I).

The visitation network was more specialized $\left(H_{2}{ }^{\prime}=0.55\right.$, Figure 1a, Table I) than the bumblebee species-pollen type network $\left(\mathrm{H}_{2}{ }^{\prime}=0.31\right.$, Figure $1 b)$. Bumblebee species differed significantly in pollen type composition (PerMANOVA: $F=2.60, R^{2}=0.20, P<0.001$, Table II). Differences in pollen type composition were most pronounced between Bombus lapidarius and Bombus hypnorum and between B. lapidarius and Bombus terrestris (PerMANOVA: both $P<0.01)$. For instance, $B$. hypnorum collected relatively large proportions of pollen from Lonicera spp. $(\sim 30 \%)$, whereas pollen collected by $B$. lapidarius was largely derived from Castanea spec, Eryngeum campestre and Trifolium pratense ( $\sim 69 \%)$, and B. terrestris collected relatively even proportions of overall 23 different pollen types (Table II, Figure 1b). B. hypnorum, Bombus pratorum, and $B$. terrestris did not differ from each other (PerMANOVA: all $P>0.05$, Table II).

In contrast, the nutritional networks were comparatively less specialized for both concentrations $\left(\mathrm{H}_{2}{ }^{\prime}=0.003\right.$, Figure $\left.1 \mathrm{c}\right)$ and proportions $\left(\mathrm{H}_{2}{ }^{\prime}=\right.$ 0.007 ) of amino acids. Different bumblebee species differed in amino acid profiles with regard to proportions (PerMANOVA: $F=2.53, R^{2}=0.21, P=$ 0.03 ), but not to concentrations (PerMANOVA: $F=1.55, R^{2}=0.14, P=0.15$ ) (Table III). However, $B$. lapidarius was the only species deviating from the others, as it had slightly, albeit significantly, lower proportions of arginine, lysine, and $\lambda$-aminobutyric acid than $B$. hypnorum (arginine and $\lambda$-aminobutyric acid) or $B$. terrestris (lysine) (Table III), whereas $B$. terrestris, $B$. hypnorum, $B$. pratorum, and $B$ terrestris showed no significant differences in the proportion of any single amino acid (Table III).

\section{DISCUSSION}

Whereas floral resource and niche partitioning among different bumblebee species has extensively been studied (Goulson 2003), nutritional partitioning (with regard to chemical composition of composed diets) has hardly been investigated in 
Table I. Bumblebee pollen and nectar foragers, the plant species they were captured from as well as the number of different pollen types (i.e., morphospecies, N Pollen) and the percentage of pollen from the sampling plant species (Pollen [\%]) of pollen foragers.

\begin{tabular}{|c|c|c|c|c|c|}
\hline Bumblebee species & $\mathrm{N}$ & Plant species & Plant family & N Pollen & Pollen [\%] \\
\hline \multirow{4}{*}{$\begin{array}{l}\text { Pollen foragers } \\
\text { Bombus humilis }\end{array}$} & 50 & & & & \\
\hline & 1 & Ajuga reptans & Lamiaceae & - & - \\
\hline & 2 & Glechoma hederacea & Lamiaceae & 2 & $?$ \\
\hline & 2 & Trifolium pratense & Fabaceae & 2 & 42 \\
\hline \multirow[t]{5}{*}{ Bombus hypnorum } & 1 & Lamium album & Lamiaceae & - & - \\
\hline & 1 & Ajuga reptans & Lamiaceae & 14 & $?$ \\
\hline & 1 & Trifolium pratense & Fabaceae & - & - \\
\hline & 2 & Lonicera spp. & Caprifoliaceae & 1 & 100 \\
\hline & 2 & Salvia pratensis & Lamiaceae & $6 \pm 1$ & $?$ \\
\hline \multirow[t]{4}{*}{ Bombus lapidarius } & 1 & Potentilla reptans & Rosaceae & 11 & $?$ \\
\hline & 2 & Lamium album & Lamiaceae & $3 \pm 1$ & $75 \pm 4$ \\
\hline & 2 & Trifolium spp. & Fabaceae & $6 \pm 3$ & $?$ \\
\hline & 11 & Trifolium pratense & Fabaceae & $3 \pm 1$ & $32 \pm 18$ \\
\hline Bombus lucorum & 1 & Ajuga reptans & Lamiaceae & 2 & $?$ \\
\hline \multirow[t]{2}{*}{ Bombus pascuorum } & 1 & Lamium album & Lamiaceae & - & - \\
\hline & 1 & Lonicera spp. & Caprifoliaceae & - & - \\
\hline \multirow[t]{3}{*}{ Bombus pratorum } & 1 & Lonicera spp. & Caprifoliaceae & 1 & 100 \\
\hline & 1 & Vicia cracca & Fabaceae & 9 & $?$ \\
\hline & 1 & Plantago lanceolata & Plantaginaceae & 4 & 88 \\
\hline \multirow[t]{4}{*}{ Bombus terrestris } & 2 & Plantago lanceolata & Plantaginaceae & 1 & 100 \\
\hline & 4 & Trifolium pratense & Fabaceae & $3 \pm 1$ & $39 \pm 6$ \\
\hline & 9 & Vicia cracca & Fabaceae & $6 \pm 1$ & $?$ \\
\hline & 1 & unidentified & $?$ & 10 & - \\
\hline Nectar foragers & 110 & & & & \\
\hline \multirow[t]{3}{*}{ Bombus humilis } & 1 & Lamium album & Lamiaceae & - & - \\
\hline & 1 & Lamium spp. & Lamiaceae & - & - \\
\hline & 2 & Lonicera spp. & Caprifoliaceae & - & - \\
\hline \multirow[t]{7}{*}{ Bombus hypnorum } & 1 & Glechoma hederacea & Lamiaceae & - & - \\
\hline & 1 & Alliaria petiolata & Brassicaceae & - & - \\
\hline & 1 & Geranium pratense & Geraniaceae & - & - \\
\hline & 1 & Salvia pratensis & Lamiaceae & - & - \\
\hline & 2 & Geranium robertianum & Geraniaceae & - & - \\
\hline & 4 & Vicia cracca & Fabaceae & - & - \\
\hline & 6 & Trifolium pratense & Fabaceae & - & - \\
\hline \multirow[t]{6}{*}{ Bombus lapidarius } & 1 & Glechoma hederacea & Lamiaceae & - & - \\
\hline & 1 & Alliaria petiolata & Brassicaceae & - & - \\
\hline & 1 & Trifolium repens & Fabaceae & - & - \\
\hline & 1 & Lotus corniculatus & Fabaceae & - & - \\
\hline & 3 & Lamium album & Lamiaceae & - & - \\
\hline & 3 & Salvia pratensis & Lamiaceae & - & - \\
\hline
\end{tabular}


Table I. (continued)

\begin{tabular}{|c|c|c|c|c|c|}
\hline Bumblebee species & $\mathrm{N}$ & Plant species & Plant family & N Pollen & Pollen [\%] \\
\hline & 3 & Geranium pratense & Geraniaceae & - & - \\
\hline & 3 & Trifolium pratense & Fabaceae & - & - \\
\hline & 4 & Ajuga reptans & Lamiaceae & - & - \\
\hline & 12 & Geranium robertianum & Geraniaceae & - & - \\
\hline \multirow[t]{8}{*}{ Bombus pascuorum } & 1 & Galium aparine & Rubiaceae & - & - \\
\hline & 1 & Geranium molle & Geraniaceae & - & - \\
\hline & 1 & Salvia pratensis & Lamiaceae & - & - \\
\hline & 2 & Alliaria petiolata & Brassicaceae & - & - \\
\hline & 2 & Lonicera spp. & Caprifoliaceae & - & - \\
\hline & 2 & Geranium pratense & Geraniaceae & - & - \\
\hline & 3 & Lamium album & Lamiaceae & - & - \\
\hline & 3 & Glechoma hederacea & Lamiaceae & - & - \\
\hline \multirow[t]{7}{*}{ Bombus pratorum } & 1 & Glechoma hederacea & Lamiaceae & - & - \\
\hline & 1 & Lonicera spp. & Caprifoliaceae & - & - \\
\hline & 1 & Prunella vulgaris & Lamiaceae & - & - \\
\hline & 1 & Trifolium pratense & Fabaceae & - & - \\
\hline & 1 & Vicia cracca & Fabaceae & - & - \\
\hline & 3 & Salvia pratensis & Lamiaceae & - & - \\
\hline & 4 & Ajuga reptans & Lamiaceae & - & - \\
\hline \multirow[t]{12}{*}{ Bombus terrestris } & 1 & Lonicera spp. & Caprifoliaceae & - & - \\
\hline & 1 & Lamium album & Lamiaceae & - & - \\
\hline & 1 & Glechoma hederacea & Lamiaceae & - & - \\
\hline & 1 & Alliaria petiolata & Brassicaceae & - & - \\
\hline & 1 & Prunella vulgaris & Lamiaceae & - & - \\
\hline & 1 & Geranium pratense & Geraniaceae & - & - \\
\hline & 1 & Plantago lanceolata & Plantaginaceae & - & - \\
\hline & 3 & Geranium robertianum & Geraniaceae & - & - \\
\hline & 4 & Ajuga reptans & Lamiaceae & - & - \\
\hline & 4 & Salvia pratensis & Lamiaceae & - & - \\
\hline & 6 & Trifolium pratense & Fabaceae & - & - \\
\hline & 7 & Vicia cracca & Fabaceae & - & - \\
\hline
\end{tabular}

Note that pollen loads were only analyzed palynologically for 39 pollen foragers. Question marks indicate those loads where the pollen type of the sampling plant species was not among the identified types, but could still be among the non-identified types. $\mathrm{N}$ gives the number of foragers captured overall and at each plant species

social insects, despite its potential importance in structuring insect societies (Lihoreau et al. 2015). Generalist bumblebee species typically visit a relatively broad spectrum of flowers and show a comparatively low, but significant, level of plant partitioning (Hanley et al. 2008; Fründ et al. 2010; Hülsmann et al. 2015). Likewise, different bumblebee species broadly overlap in the spectra of plant species visited for pollen collection but do differ in the proportion of pollen collected from each plant species (Hanley et al. 2008; Leonhardt and Blüthgen 2012).

Despite the different pollen foraging patterns observed and in contrast to our expectations, we found highly similar amino acid profiles in pollen collected by different bumblebee species, 


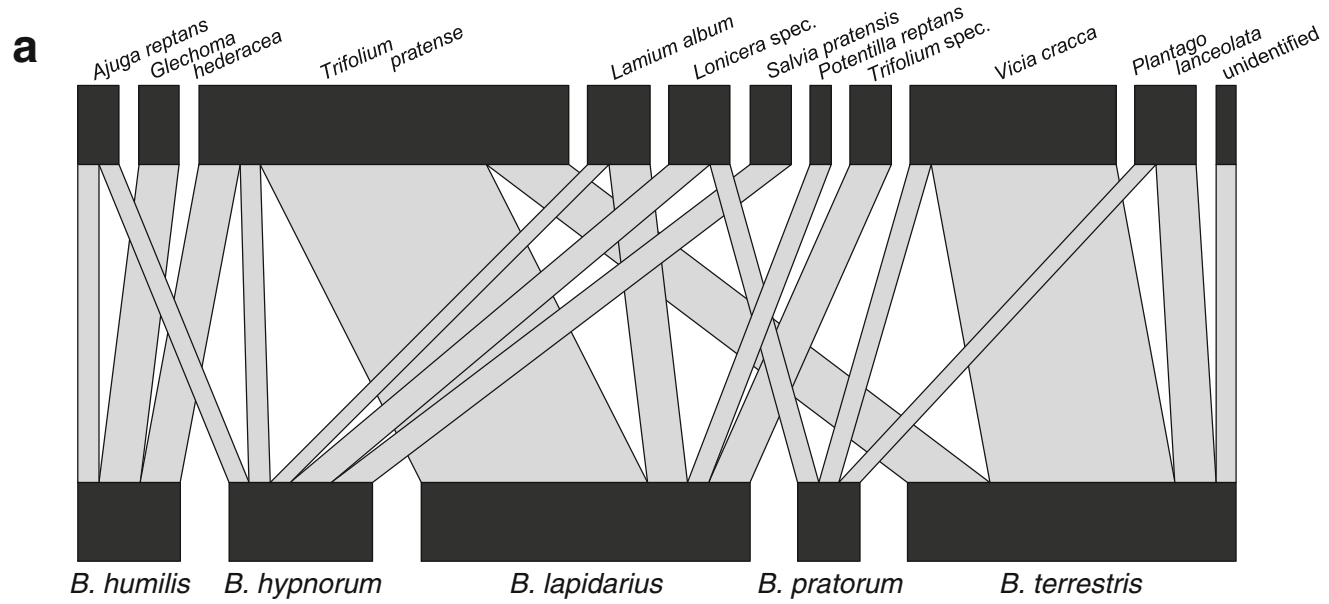

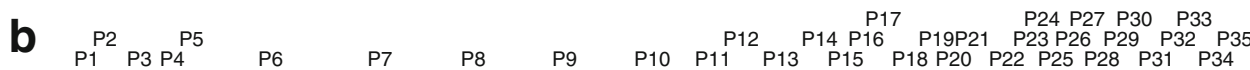

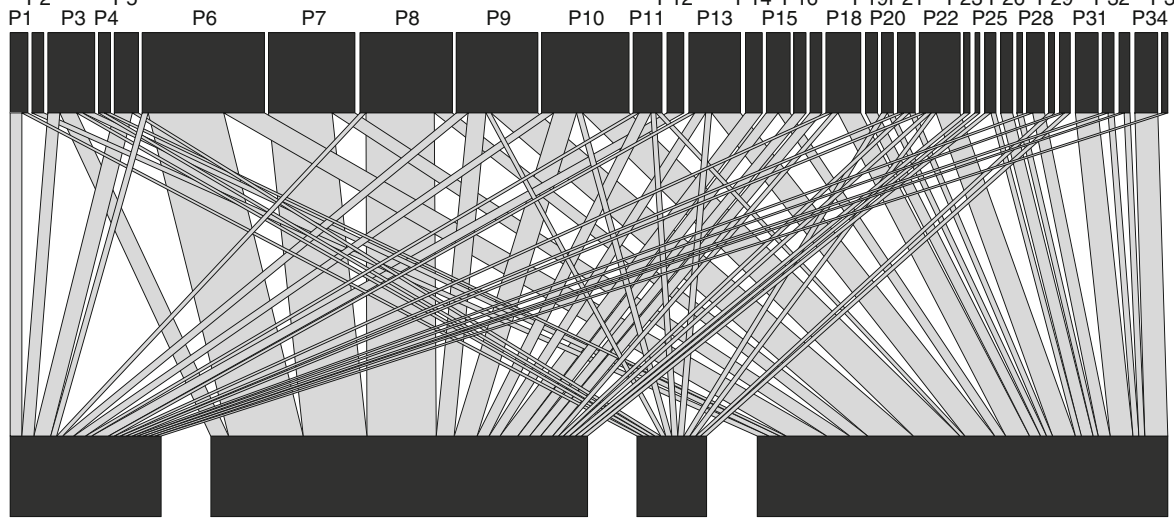

B. hypnorum

B. lapidarius

B. pratorum

B. terrestris

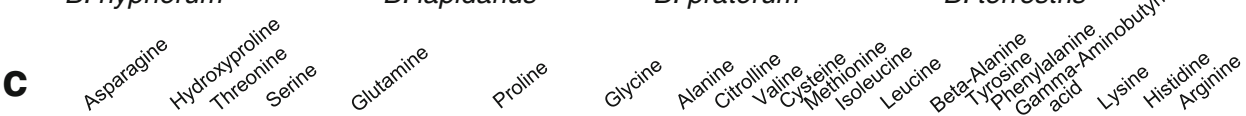

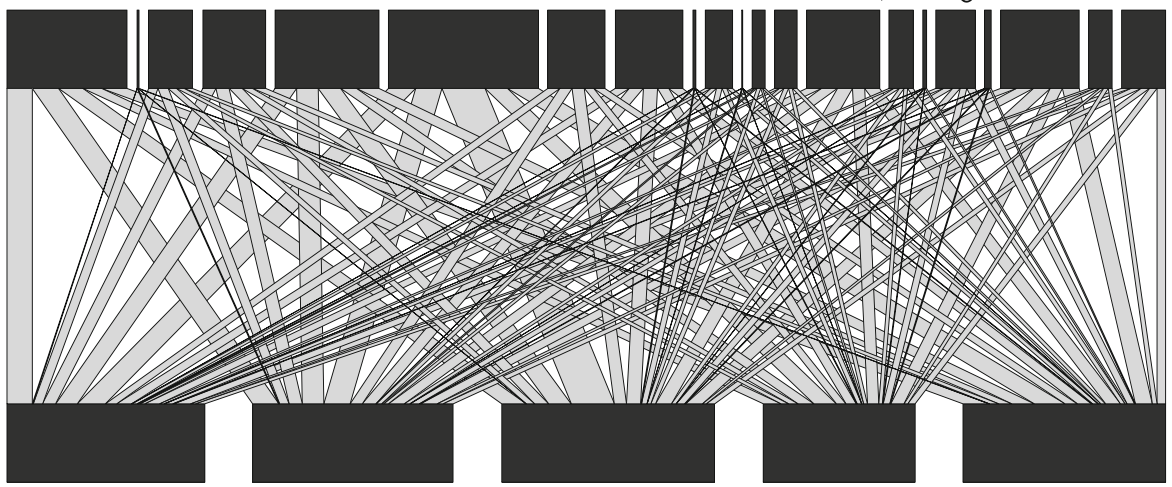

B. humilis

B. hypnorum

B. lapidarius

B. pratorum

B. terrestris

Figure 1. Visitation network (a), pollen type network (b), and nutritional network (c), representing four/five bumblebee species (bottom) and 11 plant species visited (a), 35 pollen types collected (b), or amino acid concentrations in pollen (c) (top); block width represents proportion of interactions each plant species (a), pollen type (b), amino acid (c) (bottom) or bumblebee species (top) is involved in across all samples; grey line width between blocks also corresponds to the number of interactions. 


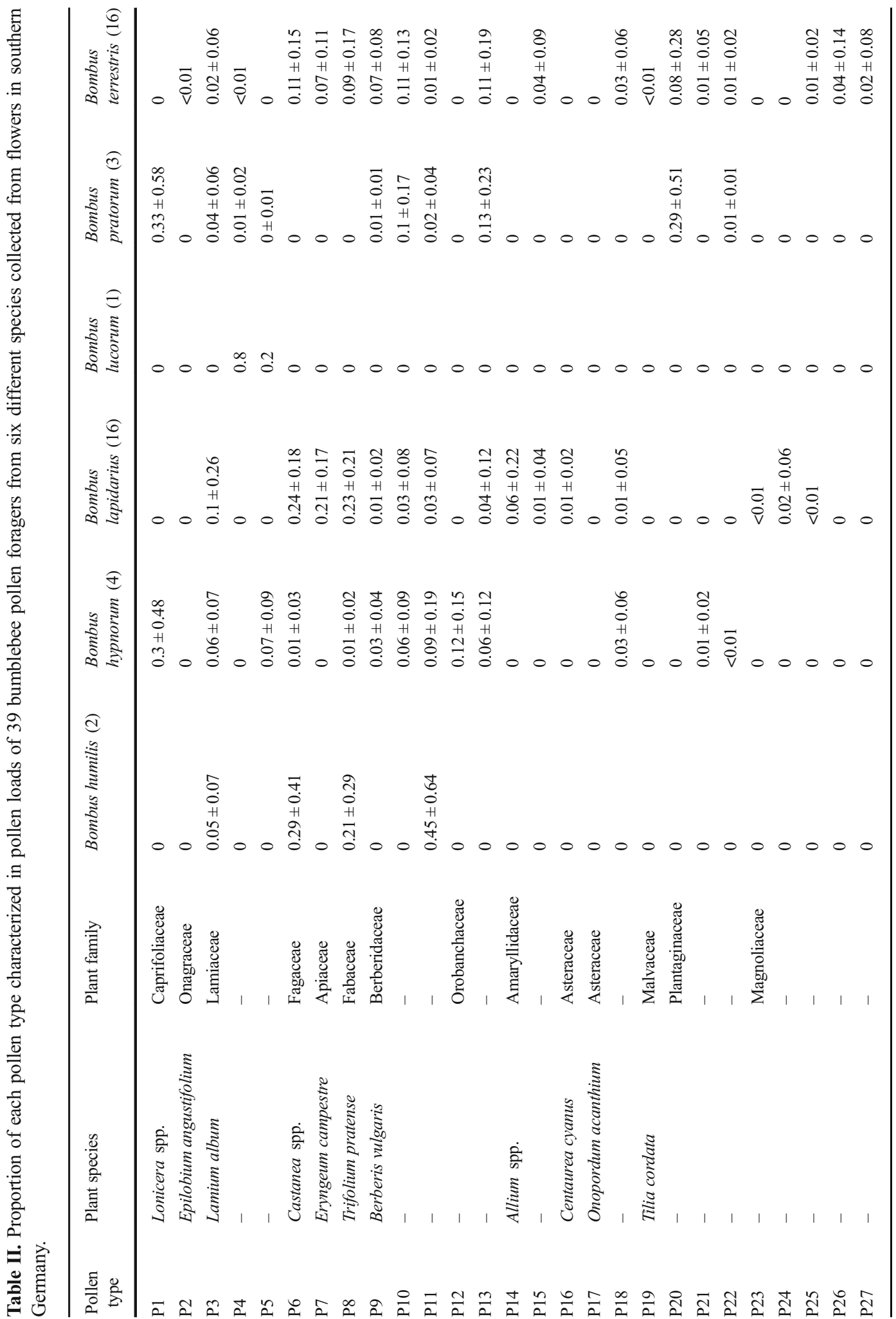




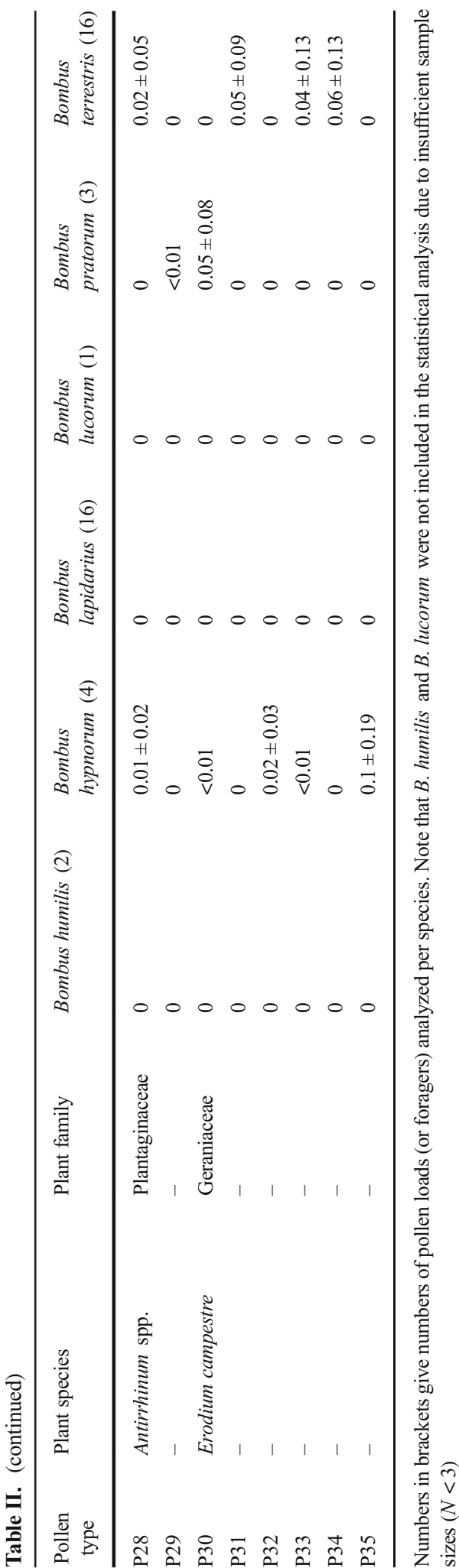

indicating that all of the common bumblebee species studied here collect pollen of relatively similar protein quality. Such similar pollen quality may result from similar amino acid profiles in pollen of plant species visited for pollen collection. While pollen of different plant species can strongly vary in the concentration of overall protein and of single amino acids (Roulston and Cane 2000; Weiner et al. 2010), it typically contains similar proportions of (essential) amino acids (Weiner et al. 2010; Moerman et al. 2015; Somme et al. 2015). Closely related plant species further have similar pollen amino acid profiles, while amino acid profiles differ between more distantly related plant species (Weiner et al. 2010; Somme et al. 2016). Because all bumblebees in our study collected pollen from similar plants (albeit in different proportions), they may have composed pollen loads of similar amino acid compositions despite different visitation patterns.

Interestingly, average proportions of amino acids in pollen loads of bumblebees studied here and considered essential for honeybees (according to de Groot 1953) and most likely also bumblebees (Génissel et al. 2002) closely resembled the minimum levels necessary for maintenance, repletion, and growth in honeybees as defined by de Groot (1953). However, bumblebees did collect pollen of on average slightly higher proportions of lysine ( $\sim 7 \%$ in bumblebees, $3 \%$ in honeybees), threonine (4-5\%, $3 \%)$, and leucine (7\%, $4.5 \%)$ and lower proportions of isoleucine $(2 \%, 4 \%)$. Proportional amino acid requirements may thus slightly differ between honeybees and bumblebees, as also indicated by previous findings (Leonhardt and Blüthgen 2009). However, while minimum required levels of essential amino acids are known for honeybees, they still have to be determined for bumblebees.

The only species that slightly deviated from the common amino acid composition pattern found in our study was $B$. lapidarius . This species collected pollen of highest methionine concentrations but comparatively lower proportions of arginine, lysine, and $\lambda$-aminobutyric acid. Moreover, pollen collected and analyzed for $B$. lapidarius contained overall highest protein concentrations and was dominated by pollen from $T$. pratense (albeit mixed with pollen from other plant 


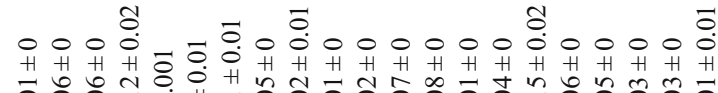

暑

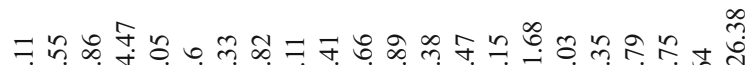
OH H H

₹

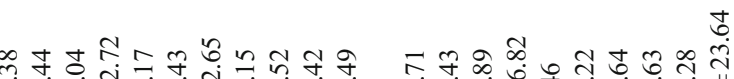

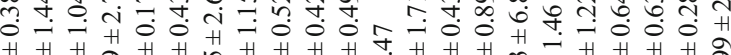
H H H H H H H H H H H H H H H

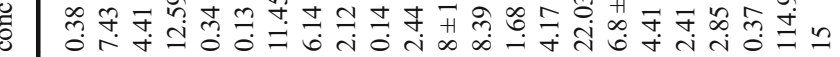

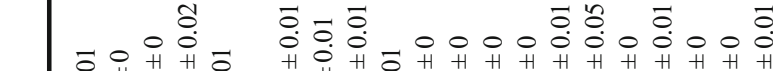

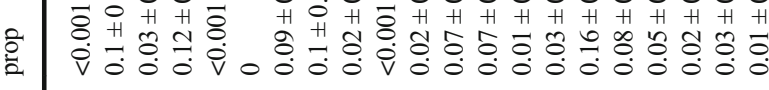

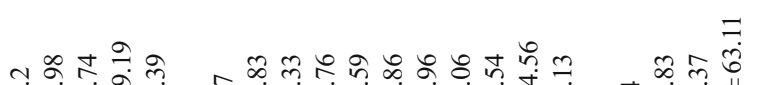

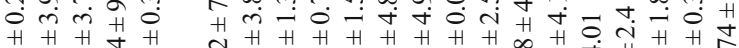

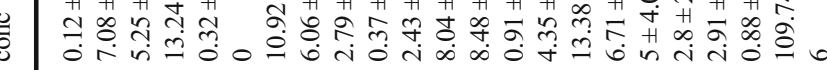




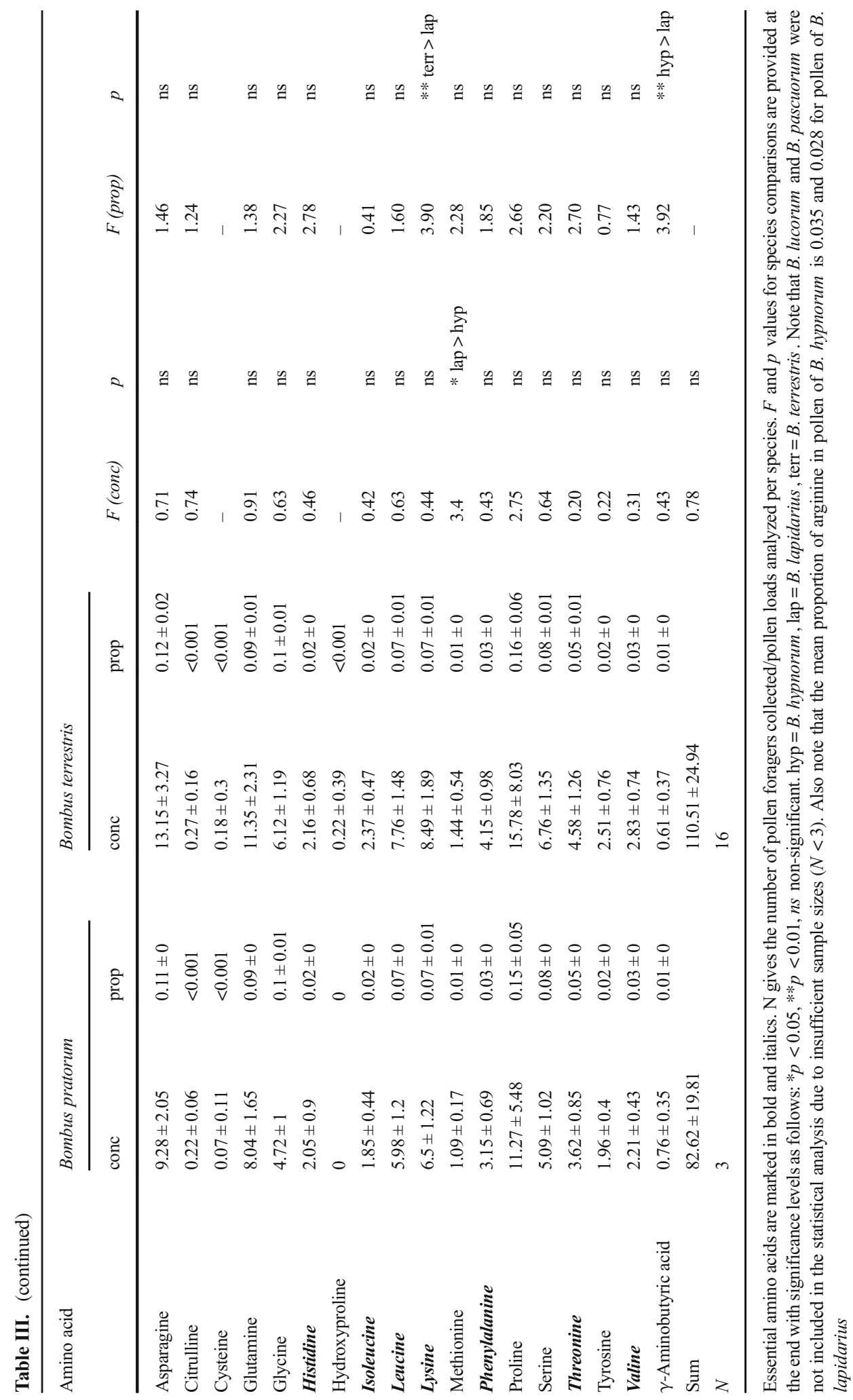


species), suggesting that this species may be more selective with regard to pollen amino acid content and/or composition than some of the other species (e.g., B. terrestris ).

A clear limitation of our study is the small sample size for some species (e.g., B. pratorum). Although we performed an extensive survey over several months and only included species with three or more pollen loads sampled in the statistical analyses, reliable conclusions can most likely only be drawn for $B$. terrestris and $B$. lapidarius both with 15 or more pollen samples. Given the low intraspecific variation in amino acid proportions for the other species (Table III), it is however all the more surprising that we did not detect more species-specific differences in amino acid profiles, which strengthens our findings.

Interestingly, in our study, pollen loads of foragers captured at a specific plant species often contained more than one pollen type and not necessarily the one from the sampling plant species. Such mixed pollen loads were also found in previous studies, but the degree of pollen mixing in specific bumblebee species varied among studies (Goulson and Darvill 2004; Carvell et al. 2006; Leonhardt and Blüthgen 2012; Somme et al. 2015) and seems to be predominantly determined by the plant community present at a given site. So, why do individual foragers of nearly all species occasionally mix pollen loads?

Mixing pollen may dilute toxic compounds (Eckhardt et al. 2014) or compose a diet closest to the bees' required optimum (which enables maximal possible individual or colony fitness), as the optimal ratio of nutrients (this is the stoichiometric relationship among all essential micro- and macronutrients that best supports an animal's metabolic functions and hence fitness) is hardly ever found in resources provided by plants (Simpson and Raubenheimer 2012). If mixing was indeed used to balance the chemical composition of pollen loads, mixing at the individual forager level should be more pronounced in bee species which do not store pollen for longer periods but directly feed it to their young. This surely is the case for bumblebees with their primitively eusocial colonies which lack complex intra-colonial feedback mechanisms (Goulson 2003). Bumblebee larvae consequently depend much more on the nutritional quality of individual pollen loads than larvae of mass-provisioning bee species, such as honeybees or stingless bees, where nurses supervise cell provisioning and thus likely also the nutritional quality of larval food. This dependence on individual foragers may explain why individual bumblebee foragers attempt to maximize protein pollen/total amino acid content more than other social bees (Rasheed and Harder 1997; Hanley et al. 2008; Leonhardt and Blüthgen 2012; Somme et al. 2015).

Alternatively, pollen mixing may simply result from maximizing pollen load quantity for a specific patch (while minimizing time spent moving between patches) and may thus increase when some plant sources have already been (partly) depleted. Such purely opportunistic foraging can however not explain why bumblebees preferentially collect pollen of high protein content. A combination of both explanations (nutrient balancing and minimizing moving time) seems thus most likely (Rasheed and Harder 1997).

In fact, pollen foraging patterns in bumblebees may be driven more by spatial and temporal conditions than by intrinsic or speciesspecific floral preferences (Roulston and Goodell 2011). Bumblebees thus seem to apply a flexible foraging strategy to compose a site-specific ideal pollen diet (Rasheed and Harder 1997; Saifuddin and Jha 2014). Our study further suggests that different bumblebee species follow similar strategies or foraging rules to meet their colonies' nutritional needs with regard to pollen and may thus show similar nutritional requirements. Their exact nutritional requirements as well as whether they actively target specific amino acid proportions or nutrient ratios needs, however, to be determined by laboratory assays.

Future studies should also expand observations and analyses to more species and more (different) sites in order to pin down the precise ecological and/or phylogenetic factors determining nutritional niches occupied by different (bumble) bee species. 


\section{ACKNOWLEDGMENTS}

We thank Matthias Jäger for preparing and providing the reference collection of pollen grains and Fabian Ruedenauer for his helpful comments. We further thank two anonymous reviewers for their great help with improving the manuscript. Funding for SDL was provided by the Deutsche Forschungs-Gemeinschaft (DFG project: LE 2750/1-1 and LE 2750/5-1).

\section{COMPLIANCE WITH ETHICAL STANDARDS}

Authors' contributions SDL originally formulated the idea, conceived, and designed the experiments. $\mathrm{LK}$ and $\mathrm{AH}$ performed the experiments. $\mathrm{LK}, \mathrm{AH}$, and SDL analyzed the data. SDL wrote the manuscript.

Conflict of interest The authors declare no conflict of interest.

Différent tout en étant semblable: les espèces de bourdon récoltent du pollen à partir de plantes différentes mais avec un profil en acides aminés similaire

Bombus / approvisionnement / nutrition des insectes / intéractions plante-insecte / compositon chimique / pollen / utilisation des ressources

Unterschiedlich und doch gleich: Hummeln sammeln Pollen von unterschiedlichen Pflanzen aber mit ähnlichem Aminosäurenspektrum

Sammelverhalten von Bienen / Insektenernährung / Pflanzen-Insekten-Interaktionen/ Pollenchemie / Resourcennutzung

\section{REFERENCES}

Amiet, F. (1996) Hymenoptera Apidae, 1. Teil. Allgemeiner Teil, Gattungsschlüssel, Die Gattungen Apis, Bombus und Psithyrus . - Insecta Helvetica.

Avni, D., Hendriksma, H.P., Dag, A., Uni, Z., Shafir, S. (2014) Nutritional aspects of honey bee-collected pollen and constraints on colony development in the eastern Mediterranean. J Insect Physiol 69, 65-73

Behmer, S.T. (2009) Insect herbivore nutrient regulation. Annu Rev Entomol 54, 165-187
Beug, H.-J. (2004) Leitfaden der Pollenbestimmung: für Mitteleuropa und angrenzende Gebiete. Dr. Friedrich Pfeil, München

Biesmeijer, J.C., Roberts, S.P.M., Reemer, M., Ohlemuller, R., Edwards, M., Peeters, T., Schaffers, A.P., Potts, S.G., Kleukers, R., Thomas, C.D., Settele, J., Kunin, W.E. (2006) Parallel declines in pollinators and insectpollinated plants in Britain and the Netherlands. Science 313, 351-354

Blüthgen, N., Menzel, F., Blüthgen, N. (2006) Measuring specialization in species interaction networks. BMC Ecology 6

Carvell, C., Westrich, P., Meek, W.R., Pywell, R.F., Nowakowski, M. (2006) Assessing the value of annual and perennial forage mixtures for bumblebees by direct observation and pollen analysis. Apidologie 37, 326340

Cook, S.M., Awmack, C.S., Murray, D.A., Williams, I.H. (2003) Are honey bees' foraging preferences affected by pollen amino acid composition? Ecol Entomol 28, 622-627

de Groot, A.P. (1953) Protein and amino acid requirements of the honey bee (Apis mellifera L.). Physiologia Comparata et Oecologia 3, 197-285

Di Pasquale, G., Salignon, M., Le Conte, Y., Belzunces, L.P., Decourtye, A., Kretzschmar, A., Suchail, S., Brunet, J.-L., Alaux, C. (2013) Influence of pollen nutrition on honey bee health: do pollen quality and diversity matter? Plos One 8, e72016

Eckhardt, M., Haider, M., Dorn, S., Müller, A. (2014) Pollen mixing in pollen generalist solitary bees: a possible strategy to complement or mitigate unfavourable pollen properties? J Anim Ecol 83, 588-597

Fründ, J., Linsenmair, K.E., Blüthgen, N. (2010) Pollinator diversity and specialization in relation to flower diversity. Oikos 119, 1581-1590

Génissel, A., Aupinel, P., Bressac, C., Tasei, J.N., Chevrier, C. (2002) Influence of pollen origin on performance of Bombus terrestris micro-colonies. Entomol Exp Appl 104, 329-336

Goulson, D. (2003) Bumblebees: their behaviour and ecology. Oxford University Press, New York

Goulson, D., Darvill, B. (2004) Niche overlap and diet breadth in bumblebees; are rare species more specialized in their choice of flowers? Apidologie 35, 55-63

Goulson, D., Hanley, M.E., Darvill, B., Ellis, J.S., Knight, M.E. (2005) Causes of rarity in bumblebees. Biol Conserv 122, 1-8

Goulson, D., Hanley, M.E., Darvill, B., Ellis, J.S. (2006) Biotope associations and the decline of bumblebees (Bombus spp.). J Insect Conserv 10, 95-103

Goulson, D., Nicholls, E., Botias, C., Rotheray, E.L. (2015) Bee declines driven by combined stress from parasites, pesticides, and lack of flowers. Science 347, 1255957

Hanley, M.E., Franco, M., Pichon, S., Darvill, B., Goulson, D. (2008) Breeding system, pollinator choice and 
variation in pollen quality in British herbaceous plants. Funct Ecol 22, 592-598

Hines, H.M., Hendrix, S.D. (2005) Bumble bee (Hymenoptera: Apidae) diversity and abundance in tallgrass prairie patches: effects of local and landscape floral resources. Environ Entomol 34, 1477-1484

Hülsmann, M., von Wehrden, H., Klein, A.M., Leonhardt, S.D. (2015) Plant diversity and composition compensate for negative effects of urbanization on foraging bumble bees. Apidologie 46, 760-770

Keller, I., Fluri, P., Imdorf, A. (2005) Pollen nutrition and colony development in honey bees: part I. Bee World 86, 3-10

Kitaoka, T.K., Nieh, J.C. (2009) Bumble bee pollen foraging regulation: role of pollen quality, storage levels, and odor. Behav Ecol Sociobiol 63, 501-510

Klein, A.M., Vaissiere, B.E., Cane, J.H., Steffan-Dewenter, I., Cunningham, S.A., Kremen, C., Tscharntke, T. (2007) Importance of pollinators in changing landscapes for world crops. Proc R Soc Lond B 274, 303-313

Leonhardt, S.D., Blüthgen, N. (2009) A sticky affair: resin collection by Bornean stingless bees. Biotropica 41, 730-736

Leonhardt, S.D., Blüthgen, N. (2012) The same, but different: pollen foraging in honeybee and bumblebee colonies. Apidologie 43, 449-464

Lihoreau, M., Buhl, J., Charleston, M.A., Sword, G.A., Raubenheimer, D., Simpson, S.J. (2015) Nutritional ecology beyond the individual: a conceptual framework for integrating nutrition and social interactions. Ecol. Lett 18, 273-286

Mänd, M., Mänd, R., Williams, I.H. (2002) Bumblebees in the agricultural landscape of Estonia. Agric Ecol. Environ 89, 69-76

Manning, R. (2001) Fatty acids in pollen: a review of their importance for honey bees. BeeWorld 82, 60-75

Michener, C.D. (2007) The bees of the world. John Hopkins University Press, Baltimore \& London

Moerman, R., Vanderplanck, M., Roger, N., Declèves, S., Wathelet, B., Rasmont, P., Fournier, D., Michez, D. (2015) Growth rate of bumblebee larvae is related to pollen amino acids. J. Econ. Entomol. epub tov279.

Neff, J.L., Simpson, B.B. (1993) Bees, pollination and plant diversity. In: Gauld, I.D., LaSalle, J. (eds.) Hymenoptera and Biodiversity. CAB International, Wallingford

Nicolson, S.W. (2011) Bee food: the chemistry and nutritional value of nectar, pollen and mixtures of the two. Afr Zool 46, 197-204

Oksanen, J., Blanchet, F.G., Kindt, R., Legendre, P., Minchin, P.R., O'Hara, R.B., Simpson, G.L., Solymos, P., Henry, M., Stevens, H., Wagner, H. (2015) vegan: Community Ecology Package. R package version 2.2-1. http://CRAN.R-project.org/ package $=$ vegan

Potts, S.G., Biesmeijer, J.C., Kremen, C., Neumann, P., Schweiger, O., Kunin, W.E. (2010a) Global pollinator declines: trends, impacts and drivers. Trends Ecol Evol 25, 345-353

Potts, S.G., Roberts, S.P.M., Dean, R., Marris, G., Brown, M., Jones, R., Settele, J. (2010b) Declines of managed honeybees and beekeepers in Europe. J Apic Res 49, $15-22$

R Development Core Team. (2015) R: A language and environment for statistical computing, URL http:// www.R-project.org. R Foundation for Statistical Computing, Vienna.

Rasheed, S.A., Harder, L.D. (1997) Economic motivation for plant species preferences of pollen-collecting bumble bees. Ecol Entomol 22, 209-219

Rayner, C.J., Langridge, D.F. (1985) Amino acids in beecollected pollens from Australian indigenous and exotic plants. Aust. J. Exp. Agric 25, 722-726

Regali, A., Rasmont, P. (1995) Nouvelles méthodes de test pour l'évaluation du régime alimentaire chez des colonies orphelines de Bombus terrestris (L) (Hymenoptera, Apidae). Apidologie 26, 273-281

Roulston, T.H., Cane, J.H. (2000) Pollen nutritional content and digestibility for animals. Plant Syst Evol 222, 187-209

Roulston, T.H., Goodell, K. (2011) The role of resources and risks in regulating wild bee populations. Annu Rev Entomol 56, 293-312

Roulston, T.H., Cane, J.H., Buchmann, S.L. (2000) What governs protein content of pollen: pollinator preferences, pollen-pistil interactions, or phylogeny? Ecol Monogr 70, 617-643

Saifuddin, M., Jha, S. (2014) Colony-level variation in pollen collection and foraging preferences among wild-caught bumble bees (Hymenoptera: Apidae). Environ Entomol 43 , 393-401

Scheper, J., Reemer, M., van Kats, R., Ozinga, W.A., van der Linden, G.T.J., Schaminée, J.H.J., Siepel, H., Kleijn, D. (2015) Muesum specimens reveal loss of pollen host plants as key factor driving wild bee decline in The Netherlands. Proc Natl Acad Sci U S A 111 , 17552-17557

Schmeil, O., Fitschen, J. (2011) Die Flora Deutschlands und der angrenzenden Länder. Quelle \& Meyer

Simpson, S.J., Raubenheimer, D. (2012) The nature of nutrition: a unifying framework from animal adaptation to human obesity. Princeton University Press, Princeton

Sokal, R.R., Rohlf, J.F. (1981) Biometry: the principles and practice of statistics in biological research. W. H. Freeman and Company, San Francisco

Somme, L., Vanderplanck, M., Michez, D., Lombaerde, I., Moerman, R., Wathelet, B., Wattiez, R., Lognay, G., Jacquemart, A.L. (2015) Pollen and nectar quality drive the major and minor floral choices of bumble bees. Apidologie 46, 92-106

Somme, L., Moquet, L., Quinet, M., Vanderplanck, M., Michez, D., Lognay, G., Jacquemart, A.-L. (2016) Food in a row: urban trees offer valuable floral 
resources to pollinating insects. Reg. Sci. Urban Econ . doi:10.1007/s11252-11016-10555-Z

Sommerville, D.C., Nicol, H.I. (2006) Crude protein and amino acid composition of honeybee-collected pollen from south-east Australia and a note on laboratory disparity. Aust. J. Exp. Agric 46, 141-149

Szczêsna, T. (2006) Protein content and amino acid composition of bee-collected pollen from selected botanical origins. J. Apic. Sci. 50

Tasei, J.N., Aupinel, P. (2008) Nutritive value of 15 single pollens and pollen mixes tested on larvae produced by bumblebee workers (Bombus terrestris, Hymenoptera : Apidae). Apidologie 39, 397-409

Vanderplanck, M., Leroy, B., Wathelet, B., Wattiez, R., Michez, D. (2014a) Standardized protocol to evaluate pollen polypeptides as bee food source. Apidologie 45, 192-204

Vanderplanck, M., Moerman, R., Rasmont, P., Lognay, G., Wathelet, B., Wattiez, R., Michez, D. (2014b) How does pollen chemistry impact development and feeding behaviour of polylectic bees? PLoS One 9, e86209
Vaudo, A.D., Tooker, J.F., Grozinger, C.M., Patch, H.M. (2015) Bee nutrition and floral resource restoration. Curr Opin Insect Sci 10, 133-141

Waser, N.M., Ollerton, J. (2006) Plant-pollinator interactions: from specialization to generalization. The University of Chicago Press, Chicago

Wcislo, W.T., Cane, J.H. (1996) Floral resource utilization by solitary bees (Hymenoptera: Apoidea) and exploitation of their stored foods by natural enemies. Annu Rev Entomol 41, 257-286

Weiner, C.N., Hilpert, A., Werner, M., Linsenmair, K.E., Blüthgen, N. (2010) Pollen amino acids and flower specialisation in solitary bees. Apidologie 41, 476487

Williams, P.H. (1986) Environmental change and the distributions of British bumble bees (Bombus Latr). Bee World 67, 50-61

Winfree, R., Aguilar, R., Vazquez, D.P., LeBuhn, G., Aizen, M.A. (2009) A meta-analysis of bees' responses to anthropogenic disturbance. Ecology 90, 2068-2076 